\title{
AN ANALYSIS OF STUDENTS' WRITING SKILL THROUGH FACEBOOK AS A MEDIA
}

\author{
Aulia Hanifah Qomar \\ Universitas Muhammadiyah Metro \\ aulya_moetz@yahoo.com
}

\begin{abstract}
The aim of this study were 1) to analyze the students' writing ability using facebook as a media, and 2) to know the classroom situations when Facebook as a media implemented in the writing class. This study is qualitative study which is carried out at Muhammadiyah University of Metro. In collecting the data, the researcher used test, observation and interview. The research findings showed that Facebook as a Media can improve the students' writing skill. Those improvements were: 1) the students' used effective word or diction choice and usage word from mastery, appropriate register; 2) the students were fluent expressions, ideas clearly stated/support, and well organized. Then, related to the classroom situation, the researcher found that: 1) teaching and learning process was more effective; 2) the students did the task given by the lecturer; 3) the students needed long time in using facebook; 4) time management was not control (internet connection).
\end{abstract}

Keywords: analysis, Facebook, writing skill

\section{INTRODUCTION}

Students have many problems when they study English. In addition, students still have a tendency to develop ideas in writing narrative texts. The problem comes from the media used by English lecturers. Their media is still not effective in boosting students' writing skills. In addition, the ability of students in developing ideas on narrative texts is still far from the English standard. Many students have many problems when they write their text.

There are two factors that can support the writing ability. Those are internal factors and external factors. Internal factors are factors that come from the perceived condition of students, ability, motivation, attention and attitudes of students. External factors are factors that come from family, place of learning and environment. One of the factors that comes from the place of learning is the media used by lecturers in writing class.

To improve the quality of writing in developing ideas in the form of text, then selected the appropriate learning media. Lecturers still use power point taken from the textbook as learning media to write. The materials taken from the textbook contain the materials that students studied in writing, especially writing narrative texts. The media used by lecturers concerned is still monotonous and less up to date. Thus, in achieving the function and purpose of learning to write, the use of facebook as media is considered effective in boosting students' writing in this study.

\section{LITERATURE REVIEW}

Hamalik (1996, p. 46) said that using the media in the learning process, can create a new desire and interest for students and to stimulate and motivate students in learning activities. Development with strict control over the use of the Internet becomes an indicator of whether students can be more creative in developing their ideas in the form of narrative texts. 
Peha (1995, p. 3) explains there are six elements contained in good writing. (1) Interesting and important ideas. Idea is the main core of writing and information to be developed. (2) a reasonable and effective organization. The organization in question is the composition of ideas in writing and flow from one idea to another idea. (3) the right emotions. The emotion in question is how the writings produced can be felt by the reader. Is it formal or informal? Is it nuanced, inviting, or rigid? Emotion is the author's personal expression conveyed through words. (4) proper and memorable selection of words. Good writing uses the right vocabulary to explain the right thing. (5) expressive and flowing sentences. The flowing sentence is easy to understand and fun to read. (6) true and communicative conventions. Conventions are agreements on punctuation, spelling, grammar, and other things that make writing seem consistent and easy to read.

Sudjana et al, (2005) explains that the internet is a visual media that can help educators in sending messages using computers as a facility for students to understand the concept of learning materials. Internet media is relatively inexpensive, easy to use, easy to enjoy and can be a message dealer in visual form. Messages inserted through communication symbols can provide a sense of enthusiasm and a sense of disability and motivation for students to participate actively in the learning process. Thus, it can be said that one of the conditions of the instructional media is as a learning tool that influences a situation, condition, and environmental learning with the intention of improving the learning process that has been created and designed by the educator (Arsyad, 2004, p. 15). Hamalik (1996, p. 46) said that using the media in the learning process, can create a new desire and interest for students and to stimulate and motivate students in learning activities.

It can be concluded that the function of internet media, especially facebook in learning can increase student motivation and as a communication tool in delivering messages (learning materials) to students with more concrete and easy to use. Facebook can be a solution to make an innovation in learning English especially in writing. In use, we use a facebook facility called a group.

\section{METHODS}

The researcher used Test Design in this research, the researcher do the test to analyze students' writing skill through facebook as a media. The researcher uses the test to do the research first. From the instrument, the researcher wants to know about the students' ability writing in narrative text. In this research there are three instruments to complete the data, they are test in the first time, continue to the observation, and then the last is the interview, with these instruments the researcher can analyze the students' writing ability through facebook as a media completely. The deepest explanation will discuss bellow:

1) Test

Test used to know the students' writing ability. Brown (1988, p. 3) explains that the test is a method to measure the ability, knowledge. The purpose of the test is to measure students' skills in writing narrative texts. The test consists of two tests: pre-test and post-test. Pre-test will be given to students before learning using facebook media. Post-tests will be given to students after learning by using facebook media applied. After both of these test have done, researchers can see whether there is an improvement of writing skills after learning using facebook media is given. 
2) Observation

Burns (1999, p. 80) explains that observation is the main core of action research. Observation is the activity of living things in terms of interpret everything that happens using the senses or record things using a scientific instrument. Researchers will observe all student activities and situations that occur during the learning process using facebook as a media.

3) Interview

Interviews are personal meetings between people because there are questions to ask and to answer. Researcher will interviews students about their personal perceptions, experiences, opinions, and ideas relating to action research in their classroom. Burns (1999, p. 118) states that interviews are very popular and widely used as a tool for collecting qualitative data. The researcher will interviews several students in the early and late stages to analyze their point of view about the learning process.

The data analysis techniques were used: descriptive statistic and constant comparative method. Iqbal Hasan (2004, p. 7) explains that descriptive statistics are part of statistics that studies how data collection and data presentation are so easy to understand. Descriptive analysis only relates to the matter of describing or providing information about a data or circumstance. Descriptive statistics serves to explain the state, symptoms, or problems. The conclusions in descriptive statistics are only directed to the existing data. In addition, the researcher also used the verification technique. The technique of verification is an essential step in the research process. This conclusion is based on organizing the information obtained in data analysis. The conclusion of this research using inductive technique that is the technique of drawing conclusions from the data that is specific to the general conclusion.

\section{FINDINGS AND DISCUSSION}

This study describes the results of the research that conducted on students of Muhammadiyah University Metro. The purpose of this study is analyze the students' writing ability using facebook as a media, and to know the classroom situations when Facebook as a media implemented in the writing class. The research results will be described in four sub stages: pre-research situation, research implementation, research results, and discussion. Everything will be explained separately and summarized in table form.

\subsection{Findings}

Pre-observation was performed before the research was conducted. The purpose of pre-observation is to know the condition of writing class at Muhammadiyah University of Metro. From the pre study found that students are familiar with internet especially facebook. Almost all students have facebook. However, 95\% of students never use facebook in the learning process. In fact, they really like to access the internet (facebook) outside of teaching and learning activities $(90 \%)$.

Pre-test has done to find out the problems faced by students related to their writing ability in detail. The researcher gave test and used a modified of assessment analysis to write the paragraph. The pre-test results showed that the student's average score was 55 .

Based on pre-observation, interviews and pre-test, the writing of sentences in preparing paragraphs and the preparation of paragraphs cohesively in a text were still low elements. This showed that students' writing skills should be improved. 


\subsection{Discussion}

\subsubsection{Discussion of Students' Responses}

Based on the interview given for the third semester of English Education Study Program of Teacher Training and Education Faculty in Muhammadiyah University of Metro. The interview was made as simple as possible to make the students able to answer easily. After knowing their problems and analysis the result of interview, below some points that could be concluded from the result of interview.

1.) Students' Responses toward English Subject

Eight students said that they like study English so much then 21 students said that they like English lesson. But 4 students said that they less like reviewed to study English at home. The media was implemented in writing class also influenced the students' motivation in writing subject. The students said that the media was too monotonous. The lecturer asked the students to write the narrative text from the handbook of writing.

2.) Students' Responses toward Lecturer

Here the researcher asked about their lecturer's way and character in teaching writing. Honestly 5 students admitted their lecturer paid attention for teaching in the class and have a good attitude. Twenty four students said that their lecturer had the best applying English for teaching. And four students said that their lecturer was not so kind in applying English for teaching especially in using a media.

\subsubsection{Discussion of Students' skill in Writing}

Based on the data gained, it was found that the students' ability in writing was good enough, because after doing the test the writer can be concluded that many students were passing from the KKM, it would be clear by the table below:

Table of the Amount of the Students in KKM

\begin{tabular}{|c|c|c|}
\hline No & 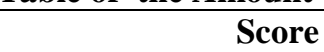 & Sum \\
\hline $\begin{array}{l}1 . \\
2 .\end{array}$ & $\begin{array}{l}\geq 55 \\
<55\end{array}$ & $\begin{array}{l}33 \\
0\end{array}$ \\
\hline
\end{tabular}

Source: Result of Writing Narrative text in The Third Semester of English Education Study Program in Muhammadiyah University of Metro on May 16, 2017.

More of half of students could write well. The researcher asked the students wrote narrative text through facebook group with theme" friendship" and from the theme, they could develop their idea, their image to make a text and to make some interesting story about the theme. In writing narrative text the students are low in vocabulary use, and still wrong in grammatically especially in using past tense, but they are using present tense to write narrative text, that is wrong, they must use past tense to write narrative text, because the characteristic of narrative is using past tense.

Based on the observation sheet about students' ability in writing through facebook as a media, the researcher could conclude that the students had the difficulty in making coda part: a moral message of the story from the writer to the reader. Then resolution part: many of the students had the difficulty in making problem solving of the conflict arises. But they had a good orientation part, because they can mention the figure and the place of the story clearly, and they had a good content. 
4.2.3 The Classroom Situation Before and After Using Facebook as a Media in Writing Subject

\begin{tabular}{|c|c|}
\hline Before Treatment & After Treatment \\
\hline a. Teaching and learning process & a. Teaching and learning process \\
\hline $\begin{array}{l}\text { 1. Students pay attention to lecturers } \\
\text { 2. Lecturers use facebook as a medium in the } \\
\text { learning process } \\
\text { 3. Students interested in following the } \\
\text { learning process }\end{array}$ & 1. Students pay attention to lecturers seriously \\
\hline $\begin{array}{l}\text { Students do not pay attention to lecturers } \\
\text { seriously }\end{array}$ & \\
\hline $\begin{array}{l}\text { 2. The media used in the learning process is } \\
\text { only power point. }\end{array}$ & $\begin{array}{l}\text { 2. Lecturers help students when using facebook } \\
\text { in the learning process }\end{array}$ \\
\hline $\begin{array}{l}\text { 3. Students are not interested in teaching and } \\
\text { learning process }\end{array}$ & $\begin{array}{l}\text { 3. Students look eager to give feedback and } \\
\text { revise the results of their work }\end{array}$ \\
\hline
\end{tabular}

\section{CONCLUSION}

This section describes the results of research that focused on the students' writing ability using facebook as a media and the strengths and the weaknesses of facebook as a media. For details, the results of the study are described below:

5.1 Students' writing skill through facebook as a media

The implementation of facebook as a media in learning writing can improve the writing skills of students. It can be seen from the result of the student's writing that the result of paragraph has described the desired topic, the students have enough knowledge about the development of the topic, the students have been able to develop the idea with coherent, the students have used vocab correctly, and the students already use punctuation and spelling correctly. This result is supported by Kasanga (1996: 76) which states that teaching writing using the internet is one method that can be used to improve teaching and learning process.

5.2 The Classroom situation after using facebook as a media

a. The learning process is more effective

b. Students look more enthusiastic in following learning especially writing courses

c. Students do the task instructed by the lecturer

d. Students' knowledge increases

e. Student activity in internet usage cannot be controlled

f. Students take a long time to access the material from the internet

g. Time management related to class situation (internet connection)

\section{REFERENCES}

Arsyad Anwar. (2004). Learning Media. Jakarta: PT King Grafindo Persada.

Brown, George and Atkins, Madeleine. (1988). Effective Teaching in Higher Education. London and New York: Routledge 
Cahyo Budiardi, Alfian \& Anggraeni, Baity. (2013). Facebook Base Writing Learning for Teaching English as a Foreign Language. Bandar Lampung. International Journal on Education Bandar Lampung $\begin{array}{lllll}\text { University. } & \text { Vol. } & 1 & \text { February } & 2017 .\end{array}$ http://journal.ubl.ac.id/index.php/IED/article/view/33

Hamalik, Oemar. (1996). Media Education. Bandung: PT Citra Aditys Bakti.

Harmers, John. (1991). The Practice of English Language Teaching. London: Longman.

Harris, J. (1993). Introducing Writing. England. Penguin Group.

Hasan, Iqbal. (2004). Analisa Data Penelitian Dengan Statistik. PT. Bumi Aksara. Jakarta.

Hornby, AS. (2002). Oxford Advanced Learner's Dictionary. Oxford University Press; New York.

Nedal A. Bani-Hani, Mahmoud A. Al-Sobh \& Abdel-Rahman H. Abu-Melhim. (2014). Utilizing Facebook Group in Teaching Writing: Jordanian EFL Students' Perceptions and Attitudes.International Journal of English Linguistics. Canadian Center of Science and Education. Vol. 4 February 2017. http://www.ccsenet.org/journal/index.php/ijel/article/view/38416

Patton, M. (1990). Qualitative evaluation and research methods. Beverly Hills, CA: Sage.

Peha, Steve. (1995). The Writing Process Notebook. Oxford University Press; New York

Qiubai, Qin. (2000). Genre Analysis and Its Implication for EFL Teaching. Lecture Notes of Summer School for Foreign Language Teacher in China, Hangzou. Zhejiang.

Sudjana, Nana \& Ahmad Rifai, 2005. Teaching Media. New York: New Light

Teng, Allen. (2012). Writing Teachers Should Comment on Facebook Walls. The National Council of Teachers of English. Vol. 19 February 2017. http://eric.ed.gov/?id=EJ97629

Wallace J, Michael. (1998). Action Research for Language Teachers. Cambridge University Press. 